\title{
O ATOR ESPONTÂNEO E SEU CORPO COMO FRONTEIRA DO PROCESSO CRIATIVO
}

\author{
PAULO ESS ${ }^{1}$ \\ ${ }^{1}$ Instituto Federal de Educação, Ciência e Tecnologia do Ceará, campus de Fortaleza. \\ $<$ pauloess@ifce.edu.br>
}

DOI: $10.21439 /$ conexoes.v10i3.842

\begin{abstract}
Resumo. O objetivo deste trabalho é estudar a expressividade do corpo do ator no teatro espontâneo e sua possível importância para o teatro brasileiro, e universal. Esta investigação se justifica especialmente pela relevância de seu objeto de estudo, como uma atividade apta para tornar possível que amplos setores da humanidade possam ascender à produção e realização do teatro e as possibilidades expressivas por ele geradas. Do ponto de vista metodológico, o presente trabalho adota para seu desenvolvimento um procedimento principal de caráter indutivo que se serve de complementos analíticos tais como estudos bibliográficos, recortes documentais, entrevistas, questionários e descrição de espetáculos.
\end{abstract}

Palavras-chaves: Teatro. Social. Corpo.

\begin{abstract}
The objective of this work is to study the expressiveness of the actor's body in spontaneous theater and its possible importance for the universal as well as for the Brazilian theater. This research is particularly justified by the importance of its subject, as an activity able to make possible that large sections of humanity can ascend to the production and realization of drama and the expressive possibilities it generates. From the methodological point of view, this paper adopts an inductive procedure which uses analytical complements such as bibliographic studies, documentary clips, interviews, questionnaires and description of shows.
\end{abstract}

Keywords: Theatre. Social. Body.

\section{INTRODUÇÃO}

Quando falamos do ator espontâneo, remetemo-nos a essa pessoa que pratica a arte da representação sem preocupar-se com conceitos teóricos e estéticos. Ele busca satisfazer seu desejo de expressar-se como ator, por meio de seu corpo. Apontamos essa manifestação como uma necessidade primordial de todo ser humano e situamos o corpo deste ator como fronteira do seu processo criativo. A partir do momento que ele estabelece seu físico como elemento criativo, traça ai uma relação direta e imediata com as outras formas artísticas. Esse ator usa seu corpo como meio de comunicação, assumindo um signo teatral. Percebemos em nossa investigação que em diversas apresentações, ele esquece a voz e dá margens ao corpo, como elemento maior da sua expressão. Assim, concordamos com o teórico Glusberg (2003, p. 76) quando afirma que, o uso do corpo como manifestação expressiva da linguagem corporal, retoma a história do homem.

$\mathrm{O}$ ator espontâneo não se preocupa com o espaço onde apresenta seus espetáculos, isso não é ponto decisivo para suas apresentações, pois ele está mais ligado à energia que desprenderá para desenvolver seus anseios. Para esse ator, qualquer espaço é cênico, possibilitando, com isso, a ativação de qualquer lugar, seja ele qual for, dando vida a qualquer ambiente, por onde passa, tornando-o um espaço vivo. O que importa o momento. Quando afirmamos isto, queremos dizer que suas apresentações não se limitam aos espaços convencionais de teatro, pois se caracterizam como evento. Nesse sentido, concordamos com o artista Marcel Duchamp, quando dizia que qualquer atitude humana poderá se transformar em um ato artístico.

Entendemos que sua arte está mais para um ato ritualístico rotineiro do que, propriamente, para um espetáculo na acepção do teatro burguês. Daí ele rompe qualquer fronteira e quebra todas as convenções estabelecidas para o teatro. Sem conhecimento de causa e sem perceber, ele quebra as regras do teatro formal.

Observando com delicadeza e juntando as informa- 
ções, constatamos que, nesse ator, concentra-se a célula da performance, pois é um artista que contesta tudo que está posto, permitindo e praticando uma arte livre de quaisquer conceitos e regras que venham a enquadrálo em uma categoria teatral, mesmo assim podemos identificá-lo em movimentos ideológicos. A performance está embasada em três pilares de sustentação que dão ênfase ao seu trabalho de ator, destacando-se a plateia, o texto (escrito ou não) e o ator performático. É possível imaginar que o ator espontâneo esteja atrelado aos espetáculos de improvisação.

\section{ATOR ESPONTÂNEO, QUEM É?}

Consideramos o ator espontâneo, dono da ação. É ele quem define seu momento e atira-se no processo criativo, tendo unicamente seu corpo como referência, sempre questionando pontos que são comuns à sociedade. Ele até pode, em processo de montagem de algum espetáculo, memorizar um texto escrito por algum autor, mas o fator autoral de criação do personagem continuará sendo sempre seu. Para esse ator, o texto não se limita somente à parte escrita pelo dramaturgo, mas a própria dramaturgia de seu corpo, como signo e fronteira de sua expressividade. Nesse sentido, a representação do ator estabelece uma relação imediata e objetiva com a plateia que, nesse tipo de espetáculo torna-se um público atuante.

$\mathrm{O}$ ator espontâneo experimenta, vivencia e a ele agrada o processo da montagem, pois, para ele, o que importa é o que se passa no processo da montagem, as diversas mudanças. Se esse ator carrega, em seu corpo, as referências de sua representação, podemos dizer que suas ações físicas são o momento em que ele passa a dar importância aos seus instrumentos físicos e concretos, que permitem a construção de sua cena. Esse conceito de ações físicas foi desenvolvido e comprovado por Constantin Stanislavski, quando se refere aos recursos físicos necessários ao bom desempenho do ator. Quando nos remetemos a Stanislavski e sua teoria sobre as ações físicas, estamos recordando que sua importância se traduz na capacidade de introduzir o ator às suas percepções e sensações, pois se acredita que dessa forma, $\mathrm{o}$ ator pode desencadear suas emoções com mais consciência, permitindo vida à cena e ao personagem, com seu físico.

A princípio, imagina-se que as ações físicas se traduzem somente em movimentos corporais, pensamento que não procede, pois essas ações fazem parte de um contexto do corpo físico. Pensando assim, ao nos remeter ao ator espontâneo e seu corpo, percebemos que este vem acompanhado de sua ânima, sua força traduzida no trabalho físico. O que interessa para si são o corpo e sua alma, elementos que são capazes de ativar sensações e emoções. Esse corpo representa, agora, a sua intimidade, o que há de mais interior de seu ser. É no interior do ser que o ator buscará seus desejos e conflitos, necessários à criação do personagem. Será o ator e seu corpo que indicará os rumos a seguir. Concretamente, o trabalho das ações físicas difundidas por Stanislavski se completa com a voz e o ritmo, necessários ao bom desempenho do ator, sobre o assunto, assim Stanislavski (1996. p. 107) se expressou:

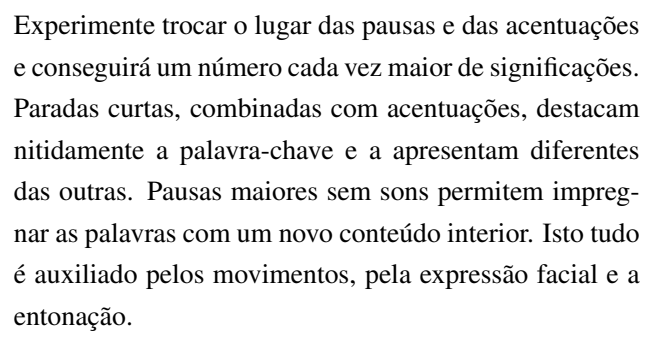

Quando partimos para a compreensão da fisiologia do corpo, não o compreendemos somente com suas funções concretas, que se situam no campo social e político. O ator não necessita conhecer, com precisão técnica, o seu físico, mas usa referências físicas que podem defini-lo e auxiliá-lo na construção dos personagens, quando percebem seu peso, temperatura, forma e sonoridade. São informações que contemplam o seu corpo, conscientizam-no da sua prática e a referendam, permitindo assim que perceba seu corpo físico, enquanto personagem. Quando ele reconhece suas possibilidades e aceita seus defeitos e virtudes, nesse sentido, ele está admitindo as informações e os dados referentes ao corpo. Seu corpo não se trata de um elemento a mais, mas, sim, um componente da comunicação. A interferência de fatores externos que inibem sua composição física são questões sociais, políticas e históricas. Esse corpo traz as influências de sua sociedade e assume postura diante dos temas por ele instigados. Seu corpo espontâneo está sempre em processo, em construção e elaboração de sua proposta física.

Percebemos um ator sempre em transformação que representa, com seu corpo, todas as suas experiências vividas e experimentadas, transformando-se em um meio de relação e comunicação com a sociedade em que convive. Não falamos do corpo passivo, mas desse corpo que, de maneira simples, se expressa quando se identifica com os outros. Um corpo que traduz a realidade dos seres humanos, um corpo múltiplo, que conta a sua trajetória e satisfaz seu contexto social e político. $\mathrm{O}$ ator espontâneo surge em sua comunidade como elemento de identificação com os demais. É por meio de seu físico que ele faz as conexões necessárias, sempre 
exercitando sua capacidade de atuação com liberdade de ação, experimentando sensações e afetos, a partir de seu processo criativo.

Com características de um corpo que se identifica com o coletivo, ele passa a ser reconhecido pelas suas peculiaridades. Um corpo que cria, elabora sua arte, incentiva a liberdade de ação, foge das interpretações grandiloquentes, esquiva-se dos clichês e personagens fechados, pois sua construção é a de uma obra aberta ao processo coletivo. Esse mesmo corpo incentiva a reflexão, questionamentos e desperta sensações, possibilitando a criação de um pensamento inquieto e polêmico, permitindo a ação dramática e o movimento físico, de forma orgânica e interna. Não podemos falar da expressividade do corpo do ator sem citarmos Etienne Decroux e sua mímica corporal, com o objetivo de estruturar os conceitos físicos para o novo ator, considerados por ele como um ser integrado, dono de seu corpo como instrumento e ferramenta para seu bom desempenho. (DECROUX, 1994, p. 76).

Para Decroux, a arte da mímica é como um trabalho artesanal, no qual o ator, com seu corpo vai esculpindo, passo a passo, sua expressividade, com paciência e precisão. Decroux nos diz que as ações físicas representam a linguagem teatral de sua expressividade física, quando, de modo meticuloso e elaborado, esse ator é capaz de trabalhar a energia nesse corpo preparado para a explosão. Conhecendo seu corpo e trabalhando seu domínio, o ator será capaz de conviver com as oposições necessárias para a prática teatral. A oposição para o físico do ator está referendada pelas forças contrárias, capazes de ativarem o tônus muscular, estabelecendo tensões. Esse ator não vivencia seu personagem, o que ele realiza é um desenho do que venha a ser o físico desse personagem, levando-o a construir ações físicas que tenham a ver com o personagem. Há uma necessidade da união entre corpo e mente, em pleno estado de ação.

Em harmonia com as ações físicas, o ator desenvolverá seu físico de modo que não se torne apenas uma máquina apta a responder a qualquer comando, mas seja capaz de estar atento às suas sensações, pois a ação física somente se completará na sua intimidade criadora. Essa busca interior estará intimamente ligada à capacidade de manipulação dessas emoções, quando usa as atividades cotidianas e as transforma em ações extracotidianas, introduzindo energias à musculatura, assim traduzindo-se em presença cênica. Identificamos o ator espontâneo como sendo o ator criador, que tira de si os componentes para estruturação de seu personagem. Para construir seus espetáculos, esse tipo de ator funde os elementos cênicos e relaciona-se com eles como uni- dade do espetáculo.

\subsection{O ator espontâneo no mundo}

Sem a preocupação de estabelecer um roteiro cronológico, podemos observar que a espontaneidade do ator no teatro vem desde épocas primitivas. Entendendo melhor a história das manifestações em culto ao deus Dionísio, percebemos que estas abrigavam em si uma estrutura espontânea, auxiliada pelas atelanas, os mimos e a dança. Dessa forma, identificamos o ditirambo como uma das primeiras manifestações do teatro espontâneo no Ocidente. Quando nos referimos ao ditirambo, estamos tratando do canto lírico improvisado, em homenagem ao deus Dionísio. O ator espontâneo dessa manifestação dançava, cantava e imitava o animal bode, em homenagem a Dionísio, no período da colheita de uvas. As pessoas, misturadas aos sátiros e dançarinos já embriagados, improvisavam e criavam, naquele instante, os personagens ((BORBA FILHO, 1950),p. 10).

\subsubsection{O ator espontâneo na Commedia Dell'arte}

Após o período do canto lírico improvisado, em homenagem ao deus Dionísio, o poeta Árion passou, então, a escrever sobre o ditirambo, deixando o caráter improvisacional. O teatro continuava com sua capacidade criadora, sempre com acesso ao improviso e à espontaneidade, tão relevante no século XVI, quando surgiu a Commedia Dell'arte, indo até o século XIX. Inicialmente denominava-se Commedia all improviso, cuja origem não se sabe ao certo. Alguns historiadores registram esse surgimento como sendo a decadência dos mimos. Desta forma Pavis (2003, p. 61) em seu Dicionário de Teatro, nos afirma que:

\footnotetext{
Não se sabe ao certo se a Commedia Dell'arte descende diretamente das farsas atelanas romanas ou do mimo antigo: Pesquisas recentes puseram em dúvida a etimologia de Zanni (criado cômico) que se acreditava derivado de Sannio, bufão da atelana romana. Em contrapartida, parece ser verdade que tais formas populares, as quais se devem juntar aos saltimbancos, malabaristas e bufões do Renascimento e das comédias populares e dialetais de RUZZANTE (1502 - 1542), prepararam o terreno para a Commedia.
}

Esse tipo de interpretação se justifica e se completa por contar com a participação coletiva, na qual a plateia ouve, discute, comenta e dá continuidade à conversa estabelecida em cena. A plateia, inspirada pela expressividade corporal dos atores que cantavam, dançavam e tocavam em suas cenas cômicas, integrava-se aos atores. E todos se tornavam aliados na propagação desse 
movimento de teatro popular. Identificamos como o grande trunfo de propagação da Commedia Dell'arte a praça como um local democrático, desde a Grécia Antiga. Os temas populares apresentavam o ser humano como um ser comum a todos os outros. Vale lembrar que essas companhias de teatro não pertenciam a nenhuma corte, rei ou príncipe da época, nem eram protegidos por ele.

Destacamos, como ponto fundamental de nossa investigação, a improvisação, tão presente nos atores da Commedia e que, também, são características decisivas do ator espontâneo, nos dias atuais. O fato é que o ato de improvisar sempre fez parte da prática humana em seu comportamento rotineiro, e, na historia do teatro, as atelanas e os mimos se destacaram porque usavam a improvisação como recurso interpretativo.

Na Commedia Dell'arte, os atores improvisavam baseados em um roteiro previamente estabelecido. Esse roteiro permanecia no fundo do palco, onde todos, durante o espetáculo, pudessem sempre consultá-lo e servia para informar as saídas e entradas dos personagens. Na improvisação, no que diz respeito aos atores da Commedia como aos atores espontâneos da atualidade, os diálogos podem evoluir e ter suas variações conforme cada ator, seguindo suas habilidades criativas. Seria a capacidade improvisacional do ator da Commedia, que se destacava e passava a ser cobiçada por outras companhias similares. Podemos afirmar que agindo assim, estava instaurado o ator profissional que passaria a ser remunerado pela sua prática teatral (OLIVA; MONREAL, 2002, p. 130). Observamos que a Commedia Dell'arte teve grande destaque e maior consistência com a propagação das festas populares, como é o caso do carnaval. Foi por meio do carnaval que se reforçou o uso da mímica como linguagem universal. Inspirados no teatro popular surgem diversas perguntas e tentando entender a origem da Commedia Dell'arte, nos auxiliamos dos autores Oliva e Monreal (2002, p. 128), quando nos afirmam que:

\footnotetext{
Três são as principais hipóteses sobre a presença de tão singular gênero. A primeira está baseada no elemento regional. Tratar-se-ia de uma evolução das formas do teatro latino como o mimo e os jaculatori. A segunda se apoia no elemento carnavalesco; neste sentido, as máscaras sugeririam a procedência da festa de carnaval, junto a celebrações ritualísticas que nela concorrem. A terceira viria como simples transformação da comédia latina; o que Sanesi chamou de vulgarização da comédia de Plauto e Terencio, teoria pouco aceita na atualidade.
}

O ator da Commedia Dell'arte tinha em seu corpo uma característica peculiar de ator campestre e com seu lirismo confundia-se como ator ingênuo. Este ator tinha em seu corpo, a cultura popular e sua riqueza original, concentrada nas regiões da Itália. Desta maneira, destacava-se a diversidade de sotaques e dialetos que definiam cada região de onde se originavam. As máscaras foram elementos de preservação deste movimento cultural, pois ainda nos dias atuais, elas são replicadas e repassadas com as mesmas características, ou seja, estão sempre relacionadas às regiões italianas.

Enfim, destacamos a Commedia dell'arte como teatro espontâneo por ser um movimento teatral popular da Idade Média, que explorava a técnica da improvisação com base em um roteiro. Era uma prática teatral que permitia a confluência de alguns tipos de cultura e expunha o teatro natural que, com técnicas espontâneas, desestruturava a estética do teatro burguês (OLIVA; MONREAL, 2002, p. 127).

\subsubsection{O ator espontâneo no The Living theatre}

O Living Theatre foi fundado em 1951 por Judith Malina e Julian Beck, em Nova Iorque e surgiu com a intenção de responder ao teatro comercial da Broadway (ASLAN, 1994, p. 296). Era um grupo idealista que se tornou ponto de referência para algumas experiências teatrais contemporâneas e se destacou pela forma como trabalhava o ator em cena. Esse grupo tem como objetivo a valorização do ator em relação com a plateia e uma analogia entre ator e sua expressão gestual sem preocupar-se com um teatro psicológico. A ideologia do Living Theatre coloca o ator em evidência quando o expõe de modo autêntico à linguagem e à expressividade do corpo. A investigação do grupo estava sempre disponível e buscava uma forma interpretativa que não estivesse ligada ao teatro psicológico. Isto implicava no aproveitamento das diversas propostas dramatúrgicas, ou seja, qualquer autor, cuja dramaturgia permitisse essa prática de liberdade de ação entre atores e plateia, era válido.

O Living contradiz qualquer forma de teatro comercial. Essa recusa não se limita somente à forma estética e sua arquitetura, mas a qualquer modo de teatro comercial quanto a sua dramaturgia e a prática dos atores. Agindo dessa maneira, os integrantes do grupo entendiam que estavam colaborando com a transformação da sociedade, tornando-a mais consciente, atuante e questionadora. Quando citamos o Living Theatre, como um grupo que questiona sua técnica teatral, é porque eles acreditavam que essa prática poderia ser um teatro para todas as pessoas, de forma democrática. E todos, atores e plateia, podiam criar, agir e dividir seus anseios, desejos, frustrações, com a intenção de transformar o meio em que vivem. O que objetivavam era uma forma 
de teatro na qual todos tivessem consciência e experimentassem a realidade. Para eles, não interessava uma prática teatral carregada de simbologia.

Em geral, os temas eram propostas que permitiam a discussão pública de assuntos polêmicos tais como o aborto, a liberação sexual, o uso de drogas. Eram questões que a plateia gostava de ver e questionar, mas que incomodavam os governantes. Para mostrar que as encenações do Living Theatre eram construídas e embasadas em improvisações e exercícios de corpo, apontamos as montagens, a seguir, por considerarmos que elas fazem referências a esta prática.

A interpretação do ator do Living Theatre baseia-se na essência humana, em que cada um deveria expressarse da melhor maneira possível. Os atores precisavam sentir-se bem em cena e atuarem do jeito que realmente são. A energia entre atores e plateia deveria fluir de suas entranhas e todos, conscientes, dizerem o que viveram. Essa prática coletiva teve bastante repercussão e aceitação por todo o mundo. No Brasil, o Living Theatre influenciou, no Rio de janeiro, o grupo Arena, o Teatro do Oprimido de Augusto Boal e o grupo Tá na Rua, de Hamir Haddad; e em São Paulo, o grupo Oficina.

\subsubsection{O ator espontâneo no Teatro do Oprimido}

Termo sugestivo e, ao mesmo tempo, polêmico, a nomenclatura Teatro do Oprimido designa o que seria essa prática teatral. É uma expressão artística de cunho histórico e político, criado pelo dramaturgo brasileiro $\mathrm{Au}-$ gusto Boal, no final da década de 1950 e inícios de 1960, que expressa seus pensamentos teóricos e práticos. O Teatro do Oprimido representa o todo dessa prática teatral, em que estão incluídas as vertentes: Teatro Jornal, Teatro Legislativo, Teatro Invisível, Arco Íris do Desejo, Teatro Imagem e Teatro Fórum.

O Teatro do Oprimido transforma o espectador em um protagonista do espetáculo, retirando-o de sua passividade. Observamos como pontos positivos a capacidade que essa técnica tem de possibilitar a qualquer pessoa o acesso à linguagem teatral e a importância que se dá ao público. Para Boal (2006), todos os que ali estão presentes na plateia, não são somente pessoas que assistem a um espetáculo, mas, sim, seres ativos. Pensando assim, cada pessoa, quando participa do espetáculo, é um espectador, e quando sente necessidade de interferir na cena, transforma-se em ator, assumindo uma duplicidade. Por conta disso, o autor criou a designação espect-ator.

A metodologia composta por esses exercícios e jogos na prática se desenvolve por meio de oficinas, seminários e laboratórios. Sua função é divulgar, avaliar e discutir a projeção dessa técnica, possibilitando que cada participante reflita sobre suas relações sociais e políticas. Nessa relação, estão incluídas as histórias do oprimido e do opressor. O objetivo do Teatro do Oprimido é trabalhar com as minorias de qualquer parte do mundo e incluí-las na sociedade à qual pertence, permitindo-lhes interlocução.

Qualquer ação que faça parte da vida humana contribuirá para este trabalho estético do Teatro do Oprimido, isto é, a confecção de instrumentos musicais, figurinos, adereços, materiais cênicos. Tudo aquilo que esteja próximo, colaborará para a construção estética dessa expressão artística, como jornais, cordões, barbantes, garrafas plásticas. Estes materiais recolhidos transformam-se em objetos, acessórios, instrumentos musicais, cenários e figurinos. Mas que estética seria esta que traduz o Teatro do Oprimido como um teatro diferenciado e com elementos próprios?

A estética do Teatro do Oprimido possui função básica que mobiliza esta expressão artística e se traduz em estilo de atuação popular. Percebendo a dinâmica desta “ação", a estética surge quando todos a praticam. Qualquer que seja a função do participante nos espetáculos do Teatro do Oprimido, ele tem a essência do material teórico que definirá a linha estética da cada espetáculo, como mostra seu criador:

\footnotetext{
A estética do Oprimido busca desenvolver, em quem a praticam, sua capacidade de perceber o mundo através de todas as artes e não só do teatro, centralizando esse processo em a palavra (todos devem escrever poemas e narrativas); senão em o som (invenção de novos instrumentos e de novos sons); e em a imagem (pintura, escultura e fotografia) (BOAL, 1975, p. 15-16).
}

Boal sugere que os temas das improvisações sejam retirados de jornais do dia, a fim de facilitar o debate ideológico e político. Os temas serão contextualizados com os problemas individuais. Ele explica o Teatro do Oprimido de maneira conceitual, começa pela estrutura, onde a "vontade" é primordial ao ator, para "querer" o personagem. Essa busca pelo personagem deve ser dinâmica e de conflito. Sua estética está baseada na investigação de maneira experimental e fundamentada na certeza de que todas as pessoas são melhores do que imaginam ser e podem fazer mais do que podem imaginar. Os temas estimulam os participantes a desenvolverem suas qualidades de conhecimento do mundo e as possibilidades de transmiti-los aos outros. A estética do Teatro do Oprimido desenvolve-se em quatro pontos: palavra falada / escrita, imagem, som. 


\section{MATERIAIS E MÉTODOS}

\subsection{Caracterização da pesquisa}

A presente investigação partiu da necessidade de compreender o ator espontâneo e a influência desta expressão. Observamos que este ator tem seu corpo como fronteira do seu processo criativo e elemento de expressão. Assim, tendo em conta aspectos relevantes do teatro contemporâneo, buscamos entender este tipo de teatro. A pesquisa em questão surgiu com a intenção de averiguarmos os aspectos sociais, políticos, artísticos e a função do corpo do ator na prática de tal arte.

Tentamos entender o teatro espontâneo a partir de sua mediação histórica, psicossocial, política ou artística; e, em seu contexto, buscamos verificar as influências, personalidades e fatos que contribuíram para a construção dessa manifestação. Quando ministrávamos aulas de teatro, tínhamos a preocupação de abordar os princípios da improvisação e da criatividade para os alunos. A convivência com estudantes que não tinham nenhum conhecimento teórico, mas desejavam serem atores, despertou-nos a curiosidade para pesquisá-los como objeto de investigação.

Para o bom entendimento do tema, aplicamos questionários para a categoria de atores e atrizes, para as entrevistas, elaboramos um esquema e, para os espetáculos e ensaios, empregamos a observação e a análise. Efetuamos uma investigação prática sobre a estrutura física dos atores do grupo estudado, durante o período de janeiro a março do ano de 2013, na cidade de Fortaleza/Ceará. O objetivo da investigação versa sobre o corpo do ator e a expressão de sua musculatura ao praticar o teatro espontâneo, a fim de situar as regiões corporais capazes de desencadear a musculatura adequada, para ativar o gesto correspondente. Com a intenção de compreender o tema, analisamos o seguinte: se o teatro espontâneo é uma expressão política e se toda ação política está contida no corpo físico, teria o teatro espontâneo sua base no corpo humano?

O embasamento teórico de nossa pesquisa levou em consideração estudos de diferentes áreas. Com relação aos conceitos do corpo, buscamos os pensamentos de LABAN (1978) e Delsarte (apud BONFITTO, 2006; ASLAN, 1994). Ao abordar a improvisação, consideramos os autores Spolin (2003.) e MORENO (1977). Para os fundamentos teóricos e conceitos sociais, contamos com os textos de Herbert Marcuse (1984) e K. R. Popper (1994). Para a teoria e História do teatro brasileiro, buscamos a obra de Sábato Magaldi (1998); e para entender a interpretação, revisamos a teoria de Stanislavski (1982), Bertold Brecht (apud PEIXOTO, 1974) e também a obra de Augusto Boal.

Analisamos o teatro espontâneo com todos os ele- mentos que o influenciam: um teatro social e político, coletivo e transformador da sociedade e das pessoas que o praticam. Analisamos os pontos decisivos desse teatro, a fim de compreender as questões sociais e artísticas. Examinamos a visão dos atores sobre a expressão dramática que eles desempenham nos espetáculos, sempre considerando a participação coletiva deles na construção da cena. Pesquisamos quais são as necessidades do ator, sua capacidade de imitação, sua aparência física ao construir o personagem.

Ainda nesta seção demonstramos, por meio de entrevistas semiestruturadas e de observações realizadas com os atores do Curso Princípios Básicas de Teatro/CPBT, do Theatro José de Alencar, a existência da prática do teatro espontâneo. Observamos as condições sociais, o nível de escolaridade e a idade de cada participante, além de analisarmos a expressividade do corpo do ator no espetáculo de conclusão do curso.

Examinamos os dados apresentados, por intermédio da observação direta dos espetáculos e das atividades desenvolvidas pelos alunos do CPBT/Theatro José de Alencar. Ao observar os espetáculos montados por esse grupo de atores, dirigimos nossa atenção ao corpo do ator e à aplicação de sua musculatura para determinadas ações, com a intenção de verificarmos se esse ator tem seu físico como fronteira de seu processo criativo. Elaboramos uma trajetória do corpo, observando a expressividade e destreza do ator, quando este se relaciona com objetos e quando aplica a razão e a emoção em seus textos.

Consideramos o Curso Princípios Básicos de Teatro, oferecido à comunidade de Fortaleza, pelo Theatro José de Alencar, como uma mostra ideal do ator espontâneo, por não ter nenhum pré-requisito para seu ingresso, permitindo, com essa democratização, uma maior quantidade de alunos que buscam essa linguagem. O programa curricular do CPBT busca uma sistemática que contemple o leigo no trato com a linguagem teatral, considerando que a própria dinâmica da vida, em sua complexidade temporal e factual, exige dos envolvidos sensibilidade e bom senso nas relações interpessoais, para que se favoreça a construção do conhecimento. Apesar de ter, como objetivo único, a prática do teatro, os alunos se distinguem por suas características sociais e intelectuais.

As referidas observações ocorreram de janeiro a março de 2013, na cidade de Fortaleza, Brasil, e os encontros realizaram-se inicialmente, às terças-feiras e quintas-feiras, das 9 às 11 horas. Depois, estenderam-se por todos os dias da semana no mesmo horário. Os processos de observação e análises mencionadas referiramse, concretamente, aos estudantes de interpretação do 
Curso Princípios Básicos de Teatro/CPBT, no Theatro José de Alencar.

O cronograma de atividades dos encontros tinha como objetivo, a evolução do entendimento da linguagem do teatro espontâneo. Isto permitiu que os alunos lessem, vivessem e experimentassem todas as técnicas desse tipo de teatro, pois nosso objetivo era perceber a coerência física e corporal de cada um deles, buscando sua unidade, dentro do entendimento de sua prática.

\subsection{Campo da pesquisa e sujeitos}

O Theatro José de Alencar foi inaugurado, em 17 de junho de 1910, pelo Presidente da chamada Província de Ceará, Antônio Pinto Nogueira Acioli. No fim do século XIX, o estado do Ceará era um grande exportador de algodão e mantinha relações culturais e econômicas com países da Europa. Foi a partir dessa relação cultural que, em 1904, uma estrutura metálica bastante original foi importada de Glasgow na Escócia. Em 1974, com a ação deletéria do tempo, essa estrutura necessitou ser recuperada e ainda hoje compõe sua arquitetura (VELOSO, 2002, p. 21). Em 1918, o Theatro José de Alencar passou por algumas adaptações, com destaque para a iluminação a gás que deu lugar à iluminação elétrica.

Na última reforma de 1989/1990, o paisagista Burle Marx recuperou sua estrutura original, concebendo um jardim com algumas plantas raras da selva brasileira. Nessa mesma época, em 1991, foi criado o Curso Princípios Básicos de Teatro - CPBT, com uma sustentável teoria e prática teatral, a fim de formar e informar atores. Os participantes do CPBT são estudantes, com idade entre 18 e 30 anos. Sua formação é $10 \%$ de graduados e $90 \%$, com ensino secundário, sendo sua renda familiar entre 3 a 5 salários mínimos. Os atores e atrizes que compõem a turma de 2012 são: Bárbara Beatriccy Bentes Pinto, Francisco Nelson de Oliveira Moreira, George Luis Athayde Lopes, Gilberlan da Silva Menezes, Isaías Vasconcelos Cruz, Jailson Rodrigues Ximenes, Jemima Kézia da Silva Aragão, Lânia Maria Silva Mendonça, Rafael do Vale Medeiros e Vitória Maria Martins Jacinto.

Observamos que os participantes tinham a idade média de 18 a 30 anos. A partir desses dados, percebemos que a idade de todos estava bastante equilibrada, chegando à conclusão que esse fator não interferiu na percepção da linguagem teatral. As confrontações da prática justificaram-se por sua complexidade e pelas particularidades das informações obtidas. Os integrantes eram estudantes de nível secundário que reservavam a maior parte de seu dia para elaborar suas tarefas escolares, comprometendo as atividades e estudos da linguagem teatral, ou vice-versa, pois quando deveriam estar na escola, eles estavam nos ensaios, situação esta gerada de conflitos familiares.

A partir dos dados obtidos, consideramos que a maioria dos participantes é de renda baixa, situando-se entre 3 e 5 salários, condição que dificultou a aquisição do material teórico e, consequentemente, a capacidade de raciocinar sobre essa linguagem e compreendê-la. Apesar desse problema, o fato de as aulas serem no Teatro José de Alencar, permitiu-lhes utilizar a biblioteca do Teatro, realizando consultas e retirando livros. O baixo poder econômico dos participantes afetou, também, a sistemática de sua participação, pois muitos não iam às reuniões por não ter, sequer, dinheiro para seu transporte até o local dos ensaios.

Ainda que esta investigação tenha um caráter qualitativo, portanto, durante o estudo, organizamos um quadro social, econômico e a média de idade de cada participante, a fim de construir um perfil sociológico desses estudantes. Fazendo isso, percebemos as variações dos níveis socioeconômicos que interferiam na percepção da qualidade da sua prática artística. A seguir, apresentamos os gráficos que constam os dados sociais, econômicos e escolares, de nossos atores observados.

\section{ANÁLISE E INTERPRETAÇÃO DOS DADOS}

Com as observações, tivemos como meta desvendar a existência da linguagem teatral que uniria todos os atores, na relação da coerência com suas práticas rotineiras. Percebemos que a referida linguagem era empregada pelo desejo que os integrantes tinham de trabalhar nesse tipo de teatro popular e espontâneo. Respaldado pelo acompanhamento diário em sala de aula, fotografamos os exercícios, gravamos as declarações em fita cassete e registramos os espetáculos em vídeo.

O intercâmbio entre alunos possibilitou experiências surgidas com novos conceitos de um fazer teatral, com os mesmos objetivos. As influências recebidas de cada bairro, ou comunidade, onde eles estão localizados, é o que estabelece as diferenças entre cada um deles. Consideramos essa interação bastante salutar porque permite o diálogo, o estudo, o debate e o questionamento sobre a prática desses participantes, identificando-os por meio da linguagem teatral. Observamos, ainda, que em qualquer grupo, por mais heterogêneo que seja e por mais diferenças que tenha, individualmente, cada ator, na forma de buscar seus objetivos, com seus princípios e consciência crítica, se fortalece. É evidente que esse constante intercâmbio possibilita a troca de experiências, tanto na prática como na teoria. Ressaltamos que a convivência e o intercâmbio de forma subjetiva reforçam a importância da arte para a 
humanidade e valoriza os conceitos e definições a respeito da vida.

O estudo qualitativo baseou-se analiticamente no caso do ator. Ao observá-lo, podemos admitir que esse ator tem seu corpo como fronteira do processo criativo do seu fazer teatral, com o qual se expressa, auxiliado por pontos decisivos para sua interpretação. Não estudamos um ator individualizado, como um caso particular, por considerar que essa atitude não teria valor para nosso estudo qualitativo. De fato, o que nos interessou foram as comparações realizadas entre os atores coletivamente, proporcionando-nos elementos que contribuíram para a teoria geral do fenômeno em questão. Esse estudo empírico teve por base a conversa gravada, transcrita e analisada.

Percebemos que o processo criativo do gesto do ator surge a partir de uma cadeia de relações, na qual todos os músculos estão estritamente unidos. A formação do gesto e sua expressividade se situam em um sistema relacionado com as ações dos personagens, seja ele quem for. Para que esta criatividade ocorra de maneira serena e coerente, o ator faz com que a espontaneidade esteja presente na ação, expandindo-se sem limitações no processo criativo. Para isso é imprescindível que surja a improvisação como uma experiência criativa de qualquer pessoa.

Neste ponto, a criatividade transforma-se em um jogo espontâneo que envolve o individual e o coletivo. Quando se desenvolve a capacidade criadora e criativa, o corpo se envolve, em geral, em uma unidade que funciona como uma estrutura coletiva, permitindo a criatividade no jogo da improvisação. No teatro espontâneo, a capacidade de percepção reforça o poder de ampliação do processo criador. Para a liberação da criatividade, faz-se necessária como primeiro passo, a disponibilidade do ator como um ser íntegro, consciente, com vontade de produzir uma matéria subjetiva que se encontra adormecida no íntimo da pessoa. O movimento criativo será estimulado através de jogos trabalhados pelos atores e assimilados por sua musculatura.

Observamos que esses atores e atrizes têm signos e significados que não são somente corporais, mas estão, também, na essência e na alma do personagem. Sua musculatura, rosto, respiração e, consequentemente, a expressividade do corpo, são pontos onde se situa a criatividade do ator. Esses recursos físicos são as ferramentas que ele usa como manifestação artística, social e política do homem. A preparação corporal desse ator recorda-nos a trajetória do ator em geral, com seu poder de improvisação até a criação de cenas estabelecidas. Ampliando a visão do que seja o trabalho corporal, nos apoiamos em (STANISLAVSKI, 1982, p. 61) quando afirma que:

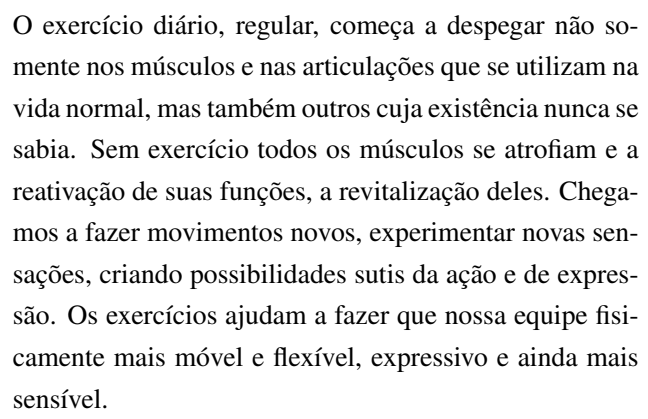

O exercício diário, regular, começa a despegar não somente nos músculos e nas articulações que se utilizam na vida normal, mas também outros cuja existência nunca se sabia. Sem exercício todos os músculos se atrofiam e a reativação de suas funções, a revitalização deles. Chegamos a fazer movimentos novos, experimentar novas sensações, criando possibilidades sutis da ação e de expressão. Os exercícios ajudam a fazer que nossa equipe fisicamente mais móvel e flexível, expressivo e ainda mais sensível.

A expressividade do corpo dos atores está relacionada com a ideia de que todo gesto expressivo é um movimento criador e criativo. O trabalho desses artistas mostra elementos de um processo criador, que estão em contínua relação, sucedendo uma ação transformada que tem como resultado o gesto artístico. Nesse caso, o processo criativo está em toda pessoa, como um ser capaz de inovar. A criatividade tão próxima ao ser humano que é chamada "talento" está mais próxima do comportamento que da capacidade de experimentar, pois é inerente a todos. A improvisação está sempre presente nesses atores e exige a criatividade necessária de cada participante para que a história surja de sua espontaneidade.

Ao observar a expressividade do corpo, descobrimos que esta se situa em movimentos rápidos, fortes e diretos. A partir da ativação física, os músculos em pares, executam uma tensão ou distensão dessa musculatura. Para observar o corpo, situamos dez regiões corporais capazes de construir uma expressão física, dando início à gênese do corpo do ator. As regiões nomeadas como fontes ativadoras do gesto expressivo serão descritas nos parágrafos seguintes.

O pescoço, por sua estratégica localização na região dorsal, além de possibilitar a sustentação da cabeça, facilita também a expressão cênica do ator. Quando ele precisa se expressar com seu rosto, essa região pode flexionar-se e se estender, inclinar para frente e para trás e realizar a rotação necessária para expressar o gesto.

Os ombros concentram as articulações do úmero e a escápula e as demais articulações da cabeça e sua cavidade.

Os cotovelos apresentam uma capacidade de amplitude que pode se aproximar dos $150^{\circ}$ e todos seus pares de músculos são capazes de dar maior expressividade a essa região.

Os punhos e as mãos tem uma estrutura anatômica que permite que o ator seja capaz de se expressar, sem usar a palavra, além de possibilitar-lhe a sensibilidade tátil. 
A coluna vertebral é constituída de trinta e três vértebras que permitem mobilidade em todo o corpo, considerada o eixo ósseo do corpo.

O tórax, importante região, guarda, em uma depressão, os pulmões, o coração e os órgãos vitais para o indivíduo. A respiração representa a entrada e a saída do ar pelos pulmões. Região importante para o ator, quando este tem consciência de sua atividade, seus movimentos respiratórios poderão ser realizados de modo relaxado, permitindo atuações e representações mais agradáveis.

A cintura pélvica e os quadris são ossos que, em sua região, auxiliados pelos músculos, são capazes de definir a postura física.

Os joelhos, considerados articulações fundamentais para cenas no plano corporal médio, compõem-se de três diferentes articulações. Tidos por muitos estudiosos como a mais complexa articulação do corpo, os movimentos articulatórios dos joelhos dos atores são capazes de lhes permitir as mais variadas expressões e posturas dos personagens.

O tornozelo e o pé sustentam todo o peso do corpo. Com sua musculatura, executam a articulação e permitem também o equilíbrio do corpo humano.

Verificamos que o ator espontâneo tem seu corpo como fronteira do seu processo criativo, e a gênese de sua expressividade se concentra em sua musculatura, porque o observando em ação, percebemos uma vasta variedade de possibilidades físicas para os personagens. Para que as posturas se elaborem com consciência e não surjam de maneira equivocada, o ator espontâneo trabalha determinadas partes de seu corpo, para assinalar as características do personagem, com o objetivo de encontrar o centro de seus anseios, sonhos e ambições.

Enfim, ao efetuarmos as observações e, posteriormente, termos relatado as experiências que esses atores praticaram, pudemos verificar que as atividades desenvolvidas demonstraram as diferenças e semelhanças entre cada um deles. Ante isto, percebemos o desejo que eles têm de interatuar, na cidade de Fortaleza/Ceará através do teatro. Consideramos que os resultados apresentados são bastante positivos, pois, com tantas dificuldades que eles tiveram que superar, ainda assim estavam motivados e interessados pela essa linguagem teatral, demonstrando sua capacidade e potencial sociopolítico.

\section{1 espetáculo}

Postos em ação, os espetáculos do teatro espontâneo não são representações com iluminação perfeita, nem com um palco impecável. É uma expressão artística que põe em prática um teatro social despojado e aberto à participação do palco e da plateia e rompe qualquer regra que distancie aos atores do público. O espetáculo representa o resultado de um acontecimento social, em que todos se relacionam e se sentem donos da ação. Esse tipo de espetáculo quase não permite um teatro chamado naturalista, ainda que, em alguma ocasião, os atores sintam a necessidade de trabalhar com esse realismo, pois esse estilo permitirá a identificação com a plateia e será, a partir do realismo, que se trabalhará sua mudança.

O objetivo do espetáculo é fazer com que as pessoas questionem suas condições sociais e políticas e assumam seu domínio ante as possibilidades que a vida proporciona. O teatro espontâneo procura colocar, nas mãos da plateia, um espetáculo capaz de despertar a reflexão sobre a essência artística e o homem em transformação. Fugindo de qualquer trabalho setorizado, o espetáculo reúne todas as linguagens artísticas, que se expressam por meio da apresentação: a plástica do palco, a riqueza da música e a investigação do figurino. O espetáculo como produto final, representa, para o grupo, a oportunidade que todos têm de mostrar suas possibilidades artísticas, oferecendo ao público, uma linguagem com diversas manifestações artísticas mais próximas do povo. O espetáculo permite que seu público tenha a lucidez da cena, momento em que se desconfia de tudo, para despertar seu raciocínio crítico.

Os conceitos dos espetáculos, esteticamente, concentram-se no trabalho do ator e no texto, sem se importar com outros elementos cênicos como, por exemplo, a iluminação. Os espetáculos, ao mesmo tempo em que questionam, também divertem e pesquisam os aspectos da linguagem teatral, tornando-se um elemento fundamental da investigação, revitalização do pensamento e libertação das pessoas. Assim, o espetáculo espontâneo expressa uma literatura popular com seus costumes, sua tradição e oralidade. Encontram-se, nessas apresentações, elementos básicos para um bom teatro, como meio de informação. A concepção desses espetáculos, em sua maioria, está centralizada no tema e no ator.

O público também se configura como elemento imprescindível. Essa plateia não é um elemento passivo ante a cena. Ela participa do jogo, está dentro da história e é capaz de contribuir com a criação do espetáculo como produto em transformação e em construção. Esse público é o criador, bem como o ator, o diretor e o autor. Está ali presente como representante de sua época, e sua contribuição é fundamental e necessária para um bom desenvolvimento do espetáculo.

O momento de participação do espectador não é de ilusão, nem de encantamento. Ele não percebe a quarta 
parede que, no teatro convencional, se faz questão que permaneça. As discussões estabelecidas não se resumem somente ao tema em si, mas ao espetáculo como um todo, quando reproduz a diversidade do grupo e sua capacidade de atuação ante a sociedade a que pertence. O espetáculo, que segue estes preceitos, não estará fechado numa proposta estática, mas permitirá a participação de todos, a partir do que está sendo exposto e discutido, respeitando os conceitos da cada um. Os espetáculos estabelecem uma relação direta entre atores e plateia, perante uma história que deverá ser contada por todos e encaminhada por situações da sociedade.

Enfim, o produto do ator é o espetáculo, arte efêmera, com características especiais, que diferem das outras. Enquanto nas demais artes, ao terminar a apresentação, ficam os registros, no teatro tudo volta ao normal subsistindo sem registro. O que foi visto ali estará registrado na memória da cada participante. Os atores são os responsáveis por criar signos necessários para a cena. Para isso, é fundamental que o ator atinja verdadeiro grau de excelência a fim de decodificar o sistema proposto pela plateia.

\subsection{Os atores}

Esse ator não busca uma formação acadêmica, mas não foge de sua condição teórica. Isto não é um recurso que impeça que uma pessoa comum se converta em ator, na medida de sua vontade e necessidade, pois seu desejo maior é contribuir com a sociedade, a partir de sua prática e percepção das questões gerais. O ator prioriza suas necessidades e compreende sua postura ante a vida, com reflexos em sua prática teatral. Sempre atento às mudanças que ocorrem a seu redor, contribui para a cena em todas as formas. Este é um ser social, que transforma o mundo e seu entorno, a partir de sua ação coletiva. Ele é um ator que mostra, em cena, as relações sociais do homem e o meio em que vive, sendo capaz de transformá-lo.

Ao elaborar a cena, esses atores que assumem os personagens não o fazem pela condição sentimental, seu compromisso está com a plateia e a renovação da arte. Esse compromisso adere o ator à plateia, motivo pelo qual the dará inteira liberdade para interferir na história. A esse ator, não interessam as interpretações grandiloquentes. A interpretação e seu crescimento artístico têm o compromisso de envolver espectadores e elenco, com o objetivo de incentivar a educação ou a prática teatral. O ator, disponível para a história, estará contribuindo para a transformação da sociedade à qual pertence, e o conteúdo de sua história que se revelará, em função desse objetivo.

$\mathrm{O}$ respeito que os atores tem pela plateia corres- ponde ao trabalho coletivo, que se adota como meta fundamental para a transformação social, através da arte. São atores sensíveis ao novo e capazes de transformar a cena, a partir da interferência coletiva da plateia. $\mathrm{O}$ modo como a plateia se sente identificada com a peça será fator importante para que o ator desempenhe, satisfatoriamente, seu personagem. Sem que seja necessário incorporar, senão representar da melhor maneira possível, o que esses atores veem são os personagens diante da história.

$\mathrm{O}$ ator assume, assim, um papel de fundamental importância, ao designar o público como testemunha daquele acontecimento, colocando-se como se fosse o personagem, a terceira pessoa dessa transformação social. Enfim, apesar da pluralidade das características que adquire o ator em várias épocas, o inusitado se apresenta; a capacidade de tornar o imaginário em real. Talvez isto seja a essência do ator. Esse ser real, capaz de se transformar em outro ser, imaginário, de ficção, teatral, que não é ele mesmo e, sobretudo conquistar por esse meio, a simpatia de outros homens (DUVIGNAUD, 1981, p. 16).

\subsection{0 texto}

Nos textos criados pelo ator espontâneo, percebemos que a unidade de ação não se condensa somente em uma ação principal, mas em várias situações, nas quais o que se apresenta tem mais importância, valorizando, também, as unidades de lugar e tempo. A falta dessas unidades remete-nos ao teatro medieval, em que a ação dos espetáculos ocorria entre os episódios, dispersando a densidade do texto. Estes se traduziam numa ação, conduzida por um narrador, que focava o ato narrado e o universo da ficção, sem a história.

Consideramos fundamental, para os textos espontâneos, as funções informativa, literária, apelativa e expressiva. As funções do texto como unidade informativa representam a grande intenção do emissor de informar, seduzir, convencer e, além de tudo isso, tratar de sugerir estado de vitalidade e entretenimento. A função informativa é, pois, introduzir o tema à história, com atenção para o enfoque social ou político. As apresentações são as que dão o sentido próprio ao texto dramático. Sempre aliado à temática social, o texto surge de ideias coletivas que serão desenvolvidas por algum integrante do grupo, com sensibilidade necessária para trabalhar a dramaturgia exigida pelo tema.

$\mathrm{O}$ espectador assume seu lugar atuante dentro do texto, quando este lhe permite fazer reflexões e questionamentos, através de diálogos e epígrafes. Ele não fala só, confabula com o personagem e com a história, como elemento transformador. É um texto aberto para 
o diálogo, para a coletividade, sem deixar de apresentar um debate sobre os problemas suscitados. Preocupase com as situações da sociedade e serve de referência para um teatro que questiona o mundo e o comportamento humano. Sua criação está unida à improvisação e à qualquer espontaneidade, expressada pelo grupo de atores, pois sua característica maior é a improvisação ou o texto coletivo sem negar a relação que as improvisações exercem na espontaneidade dos textos, por ele construídos.

Os textos são desenvolvidos em combinações e enquadramentos possíveis, com o perfil universal da figura humana. Seu estilo de escrever está contido na convenção naturalista dramática, enquanto sua caracterização transforma-se em tipos de extrato e representa a essência coletiva. Podemos citar como exemplo, os textos que circulam na sociedade e os que funcionam em situações políticas, com o objetivo de modificar os comportamentos, através da oralidade. Deste modo, podemos definir os textos como uma interação linguística, que se ajusta aos discursos das diferentes classes sociais. Podemos classificar os textos desenvolvidos pelo teatro espontâneo como uma interação linguística de uma classe social popular, porque se aplica aos diferentes setores do público e se ajusta aos diferentes discursos. Os textos buscam uma razão estética quando fazem referência a seu conteúdo. Nessa ocasião, notamos que os hábitos e costumes populares materializam o espírito político de luta, degradando as hierarquias.

Em suma, necessariamente, a dramaturgia dos textos populares é um processo criativo, que não ficará isolado e dado por concluído, após o texto acabado. Todos, ao longo das apresentações, poderão interferir na própria dramaturgia. Nessa dramaturgia, o texto não questiona a figura do autor nem o deseja abolir, mas delega a quem participa do processo criativo de elaboração do texto, a capacidade de apresentar uma partitura dramatúrgica, retirando do autor o domínio e a condição superior, de personalidade intocável.

\subsection{O cenário}

Ao se construir o cenário, este deverá se comunicar com a plateia e contar a história do espetáculo como um todo, ou seja, relacionar-se com a condição social da história. Considerado como suporte para que a história se desenvolva, o cenário conta com elementos visíveis e representa a peça que se unirá aos outros componentes necessários ao espetáculo. A iluminação e a sonoplastia estarão sempre disponíveis para contribuir com os demais elementos, bem como o figurino que surge para auxiliar a história apresentada, o cenário existirá para ambientar o texto e permitir ao espectador a vi- sualização do ambiente, de maneira concreta e situar o personagem de modo coerente.

O cenário surge como meio que dará suporte ao público para que siga sua trajetória, permite a continuidade da cena e impulsiona a história. Além de contribuir com a ação que seguirá, tem o compromisso de interagir com a cena e contribuir com o nível social dos personagens, e do espetáculo como um todo. Sua função não é a de alienar a plateia, nem também disfarçar a história, mas contribuir para que os personagens se sintam à vontade. Permite uma participação integrada entre história e público, tornando-o dono da situação. O cenário não está ali para distrair, mas para aclarar o percurso da história. É um elemento a mais, que contribuirá para o trajeto do personagem.

Ainda que essa expressão artística tenha, por si, um texto em defesa do homem como pessoa social, o recurso do cenário se torna um meio que permite maior vitalidade, como procedimento legal e necessário, para um teatro onde atores e público se convertem em donos da situação. Jamais o espaço fictício permitido pelo palco os irá distanciar, mas os impulsionará à coerência. O cenário não surge como se tivesse um efeito espiritual ou atmosférico, que possa transportar a plateia para outro plano, mas torna o espaço cênico em um lugar físico e real, capaz de contribuir com o desenvolvimento de toda a história e denunciar a situação de maneira atuante, como elemento político. A fabricação de um cenário simples permite que o ator possa desenvolver o tema, sugerir a reflexão e transformar a condição social de cada um.

Embora o ator saiba dominar a cena, o cenário permitirá que a plateia assuma sua anatomia e sinta-se dona da história. O poder do cenário situa-se como elemento de expressão e comunicação popular. Ou seja, em vez de tornar a cena carregada de magia, o cenário surgirá para usar os elementos não verbais que a cena irá permitir. Finalmente, o cenário chega para contribuir com o argumento, e oferece, para atores e plateia, uma possibilidade de sugestão sobre sua origem. São elementos cênicos básicos para o melhor desempenho da história. Na construção de um cenário, é importante que ele não seja capaz de distrair a atenção da plateia sobre a história, mas que consiga conduzir o personagem, em plena conformidade com o texto.

\section{CONCLUSÃO}

Para o estudo prático do corpo do ator espontâneo, investigamos a sua expressividade e a gênese da sua estrutura corporal, ao construir seus espetáculos e personagens. Para isso, observamos as matrizes dos personagens construídos por 10 atores/atrizes do Curso Princí- 
pios Básicos de Teatro/CPBT - Theatro José de Alencar. Percebemos a gestualidade desses personagens como forma da expressividade do grupo. A permanência de certas atitudes originárias do quotidiano, expandidas nas cenas, possibilitou desenhar a atmosfera do teatro como linguagem de transformação social, um desafio imposto e conquistado por todos os atores participantes.

Nas observações do grupo de atores estudados, notamos que o ator espontâneo, antes de ser um mero artista que exibe todas suas potencialidades vocais, corporais e intelectuais, é quem assume uma postura humanística, pedagógica e socialista de sua função, que tem como eixos fundamentais de referência, a ética e a solidariedade. Esse ator assume postura mais ampla quando promove ações sociais e objetivas, que oferecem continuidade para a sociedade. Essa prática constitui-se como o centro da questão dessa arte, quando transforma a realidade. $\mathrm{O}$ ator, em cena, tem a função de popularizar a linguagem teatral, e estabelecer o diálogo e a comunicação e despertar, no público, a curiosidade sobre o tema abordado.

Verificamos ainda que a presença constante do ator, com função diversificada, tem a capacidade de identificar a representação estética do conflito do espetáculo, qualificando-o para discutir e viabilizar os meios capazes de transformar a realidade apresentada. $\mathrm{O}$ ator usa sua espontaneidade como recurso lúdico e pedagógico, porque a considera um instrumento eficiente de interferência e comunicação social, cujo objetivo se concentra na busca das ações concretas do tema explorado. Sua capacidade de se relacionar com a plateia também oferece meios para que o público se aproprie do tema. O ator é responsável pela eliminação dos bloqueios que separam o palco da plateia e a plateia do tema apresentado e, também, pela implantação do diálogo espontâneo, democrático e popular, por meio do qual a sinceridade e a verdade devem ser expostas socialmente para todos. Em suma, este ator popular converte-se em um participante atuante.

Quando se pratica essa forma teatral surge, com maior precisão, o confronto social, pois, nesse teatro, as relações se aprofundam em temas, destacando as questões capitalistas, raciais e de gênero. Para o teatro espontâneo, qualquer pessoa, mesmo alheia a ele, será capaz de praticá-lo. Assim, o teatro espontâneo tem no eixo da expressão teatral seu maior argumento, desmistificando a linguagem teatral e reforçando a autonomia da cada um, através da arte. $\mathrm{O}$ ator não precisa fechar-se em seu mundo nem envolver-se em seu problema pessoal, porque o problema compromete toda sua comunidade. Sua função é estabelecer um dialogo que seja útil para todos. Seu trabalho está encaminhado para a melhoria da sociedade, motivando a plateia a discutir seus problemas, garantindo a diversidade das opiniões. Podemos, finalmente, dizer que o ator espontâneo não passa por formação teórica nem prática sobre o tema. Todos os atores estão em constante mudança e têm consciência de seu estado de aprendizagem.

Ademais, ao observar ao ator espontâneo, vemos que ele guarda, em seu próprio caráter cênico, sua postura física. Ainda que, com características de teatro popular, os atores traduzam-se em conceitos modernos de arte inconformista. Há uma mistura de informação e conceitos. Muitas vezes, os atores constroem personagens emblemáticos que são arquétipos da interpretação universal. As situações expostas podem muito bem ser dramáticas ou bem humoradas, mas os personagens buscam sempre se relacionar com o público. As interpretações dos atores estão refletidas em seu corpo, em que ficam marcadas as características de uma forma diferente de fazer teatro, extraídas de ações consumadas na própria cena.

Pelo exposto, chegamos à conclusão de que o método de construção dos personagens materializa o espírito do carnaval, degradando as hierarquias. Todos os atores são como reis tocados por talentos especiais que, enquanto dura o espetáculo, realizam todos seus sonhos e desejos, para além de seus limites sociais. $\mathrm{O}$ ator popular não expõe somente sua máscara facial, mas também sua máscara interna, fundindo, em uma única fisionomia, a verdade do ator espontâneo fortemente identificada com a arte de Brecht, com seus textos que provocam o público e o insultam, fazendo-o refletir.

Bem como a Commedia dell'arte, o teatro espontâneo é também uma imagem crucial do teatro popular que não se expressa só com a boca, mas com todo o corpo do ator, e aparece sem preconceitos, em forma dramática. Esse corpo absorve a energia do público e se expressa, manifestando-se como bem quer.

De maneira espontânea, o corpo é capaz de reproduzir e conceber energias férteis, que lhe dão luz própria. Assistindo a esse artista popular, observa-se sua origem grotesca, expressado em seu corpo. O gestual é parte do dia a dia dos atores, sem que fique isolado da ação, tornando-se uma atitude orgânica. O comportamento emocional, expressado pelo personagem, está relacionado com o desencadeamento muscular do momento, ou seja, o ator tensiona uma série de músculos, que lhe dá uma determinada postura física exterior. Mas, em primeiro lugar, no interior do ser humano, forma-se um sentimento espontâneo. Compreendemos que, nesse teatro, ainda que desempenhando personagens e atitudes políticas e sociais, os atores precisam dar maior atenção 
ao corpo. Por isso, buscamos situar onde se concentra a gênese do movimento do corpo do ator e as áreas e regiões físicas responsáveis pelo seu desenvolvimento gestual. Estabelecemos como pontos positivos sobre o trabalho do ator no teatro espontâneo, as seguintes considerações:

Primeiramente, a arte do teatro pode ser exercida por qualquer pessoa que, com essa iniciativa, além de praticá-la, expõe os problemas sociais enfrentados por uma comunidade; em segundo lugar, o teatro espontâneo configura-se como prática fundamental na quebra de paradigmas da linguagem teatral contemporânea; Outrossim, o entendimento da cinesiologia, como estudo da mecânica corporal, é capaz de ajudar os atores a terem maior entendimento de seus corpos, quando se refere à expressão consciente, fazendo que a partir dessa informação, estes possam ativar a musculatura adequada para a elaboração de seus personagens.

No teatro espontâneo, o ator precisa de seu corpo para praticar o diálogo imediato com os outros atores e a plateia. Esse ator jamais deverá estar envolvido com os sentimentos do personagem, porque isso poderá interferir nos sentimentos do ator com relação à história e à plateia ali presente. As destrezas corporais e vocais são fundamentais para seu bom desempenho.

O corpo expressivo do ator está sempre disponível para a construção de seus personagens. Para desenvolver as possibilidades físicas e emocionais dos atores, o grupo trabalha técnicas que explorem situações e pontos de natureza emocional da cada um e despertem o pensamento sensível. A sensibilidade estimulada possibilita o relaxamento e a libertação das tensões adquiridas ao longo da vida, as quais são capazes de bloquear o processo criativo de qualquer participante. Além do mais, a expressividade do corpo do ator não representa somente a exteriorização dos conteúdos apresentados em seus espetáculos, mas também, simboliza, para todos, a valorização das relações sociais ali presentes.

Portanto, as características emocionais são expostas no processo de trabalho do ator por meio de suas ações físicas, que podem revelar, para a plateia, os acontecimentos de seu interior. Essa expressividade converte-se em gesto social pela característica expressa nas relações entre os homens. A espontaneidade dos gestos permanece clara e definida, a fim de que a plateia perceba o tema exposto e reflita sobre ele e, para consegui-lo, a livre expressividade não deve ser reprimida. O corpo desse ator está sempre ativo e disposto a se relacionar com o outro, pois essa relação direta tem o objetivo de contar a história.

O corpo do ator, além de expressar-se com a palavra, precisa trabalhar também com o som e a imagem como parte de seu quotidiano. Compreendemos que o produto elaborado pelo corpo desse ator se caracteriza pelo emprego da espontaneidade. Para conseguir essa espontaneidade, a expressividade estará disponível para que o ator possa trabalhar qualquer situação e desenvolver qualquer tendência artística expressionista, realista ou grotesca. A tendência expressiva do espetáculo fica a critério do grupo responsável pela encenação.

$\mathrm{O}$ que poderia parecer ausência da expressividade do ator se justifica pelo que identificamos como o gesto social do ator espontâneo e se manifesta com o que seu corpo dispõe. O teatro espontâneo liberta o poder criativo e a expressividade do ator, sem que, para isso, fique limitado ao tipo físico de cada pessoa. Atuando assim, qualquer pessoa pode fazer qualquer personagem. Mulheres podem representar personagens masculinos e vice-versa. Isso permite que todos os participantes possam experimentar, sem restrições, toda a diversidade dos personagens. Cremos que essa atitude assume proporções coletivas de criação e permite que o ator possa construir, com riqueza de detalhes, a expressividade de seu personagem. Por esse motivo, o ator, além da linguagem teatral, deve conhecer assuntos diversos como psicologia, educação, política, e economia, pois o domínio de temas externos à construção cênica pode auxiliá-lo a desvelar suas capacidades e manifestar suas ideias e sentimentos mais profundos.

$\mathrm{Na}$ prática do teatro espontâneo, encontramos o corpo preparado para responder ao fluxo natural das ações que se desencadeiam, tanto por seu personagem como pelos outros. $\mathrm{O}$ ambiente onde o ator se encontra também auxilia nessa construção. Esse corpo disponível é um corpo preparado para respostas imediatas, com capacidade para atuar com maior profundidade. Observamos que esse ator, sem perceber, ativa certas partes de seu corpo, para responder a determinados estímulos exigidos pelo personagem, ou seja, sua gestualidade e mobilização cênica correspondem ao caráter do personagem. Desse modo, a expressividade física faz parte do personagem e de seu contexto na história. Entendemos que a expressividade desse ator se situa tanto em sua mobilidade como em sua postura estática, pois será essa expressividade que traduzirá, para o espectador, o estado emocional e sua mudança de atitude perante os acontecimentos abordados. Consideramos a expressividade física como o princípio de onde surgirão e se desenvolverão os gestos recorrentes.

Consideramos que a gênese do corpo, como ponto inicial para o desenvolvimento físico do personagem, dará ênfase a outros gestos que virão a seguir, e permitirá que a gestualidade produza possibilidades de expressão e dê maior liberdade para o surgimento do per- 
sonagem. Uma vez situada a gênese da expressividade, em determinada parte do corpo adequada para o sentimento exato, o corpo e o espírito do ator buscarão a harmonia do personagem. Percebemos que quando esse ator atua dessa maneira, ele está preservando o elo de conexão com os mais íntimos sentimentos, considerando que ele trabalha com arquétipos universais.

Quando afirmamos que o ator espontâneo tem seu corpo como fronteira do seu processo criativo, estamos valorizando seus elementos físicos e equipando-o com eles, os quais definirão a construção de sua gestualidade. Ademais, outros pontos contribuem para que essa seja espontânea; tais como a respiração, o texto, o uso de objetos e a relação com os outros atores. O ator, com sua capacidade física e muscular e com ajuda desses elementos, elabora sua própria técnica interpretativa, construindo um personagem palpável e humanizado, perante a plateia.

Ante as observações efetuadas, afirmamos que o momento da produção da gênese da expressividade do corpo do ator espontâneo inicia-se com a ativação consciente da musculatura, adequada para determinada gestualidade. $\mathrm{O}$ ator, ao estabelecer a gênese de sua expressividade em sua musculatura, estará eliminando qualquer possibilidade de incerteza decorrente do gesto instintivo. Nessa ocasião, não conta o gesto instintivo, mas o gesto consciente, sem que o ator tenha que perder sua espontaneidade. Será a energia do personagem a que ligará seu mundo imaginário com o exterior. Podemos afirmar que a gênese de sua expressividade se concentra em seu corpo, porque esse ator, consciente, conhece e compreende a eficácia de seu físico, e permite o funcionamento básico de seu corpo.

Finalmente, podemos ressaltar que o teatro espontâneo contribuiu, de maneira significativa, para as investigações da linguagem teatral. Supomos ter dado um passo importante para pôr o teatro espontâneo e seus atores populares como uma matriz estética para a cultura contemporânea. Acreditamos que esta investigação não se encerra aqui, pois, a partir desses tópicos, novas pesquisas podem ser realizadas, tomando como base o teatro espontâneo ou o gesto expressivo. Ao concluir, percebemos que essa forma teatral é uma obra aberta, sempre em transformação, que permite outros autores realizarem trabalhos sobre o assunto, com outra visão. Outras investigações virão, enquanto esta, em seu conteúdo, decreta o rompimento do gesto estereotipado, ensinando, aos atores e a pessoas interessadas no tema, a potência da gênese da expressividade do corpo do ator, e confirmando que o ator espontâneo tem seu corpo como fronteira do seu processo criativo.

\section{REFERÊNCIAS}

\section{REFERÊNCIAS}

AZEVEDO, S. M. de. O papel do corpo no corpo do ato. São Paulo: Editora Perspectiva S.A., 2002.

BOAL, A. Stop Cèst Magique. Rio de Janeiro: Civilização Brasiliense, 1980a.

200 Exercícios e jogos para o ator e o não ator com vontade de dizer algo através do teatro. Rio de Janeiro: Civilização Brasileira, 1982.

. O arco-íris do desejo. Rio de Janeiro: Civilização Brasiliense, 1990.

. O Teatro Legislativo. Rio de Janeiro: Civilização Brasiliense, 1996.

. Teatro do oprimido e outras poéticas políticas.

Rio de Janeiro: Civilização Brasileira, 2005.

Jogos para atores e não atores. Rio de Janeiro: Civilização Brasiliense, 2006.

BONFITTO, M. O ator compositor. São Paulo: Perspectiva, 2006.

BORBA FILHO, H. História do teatro. Rio de Janeiro: Casa do Estudante do Brasil, 1950.

BRETON, D. L. Adeus ao corpo: antropologia e sociedade. Campinas: Papirus, 2003.

CHACRA, S. Natureza e sentido da improvisação teatral. São Paulo: Perspectiva, 2010.

FELDENKRAIS, M. Consciência pelo movimento. São Paulo: Summus, 1977.

FERRACINI, R. A arte de não interpretar como poesia corpórea do ator. São Paulo: Ed. UNICAMP, 2003.

FREIRE, P. Ação cultural para a liberdade. São Paulo: Paz e Terra, 1984.

GLUSBERG, J. A arte da performance. São Paulo: Perspectiva, 2003.

GROTOWSKI, J. Em busca de um teatro pobre. Rio de Janeiro: Civilização Brasileira, 1992.

KANTOR, T. El Teatro de la Muerte. Buenos Aires: Ediciones de la Flor, 1984.

LABAN, R. von. Domínio do movimento. São Paulo: Summus Editorial, 1978. 
LANGER, S. K. Sentimento e forma. São Paulo: Perspectiva, 1980. Trad. Ana M. Goldberger Coelho.

LAPORT, N.; BEUTTENMULLER, M. da G.

Expressão vocal, Expressão Corporal. Rio de Janeiro: Forense Universitária, 1974.

LOBO, L.; NAVAS, C. Teatro do movimento: um método para um interprete criador. Brasília: LGE, 2003.

MEDINA, J. P. S. O brasileiro e seu corpo. São Paulo: Papirus, 2002.

MERLAEAU-PONTY, M. O visível e o invisível. São Paulo: Perspectiva, 2006.

MORENO, J. L. Teatro de la espontaneidad. México: Ed. Vancu C.A., 1977.

MURARO, R. M. Petrópolis: Editora Vozes, 1983.

OLIVA, C.; MONREAL, F. T. Historia básica del arte escénico. Madrid: Cátedra, 2002.

PALLOTTINI, R. Dramaturgia: construção do personagem. São Paulo: Ática, 1989.

PAVIS, P. Diccionario de teatro. Dramaturgia, estética, semiologia. Madrid: Ediciones Paidós Ibérica S.A., 1990.

_. Dicionário de teatro. São Paulo: Perspectiva, 2003.

RASCH, P. J.; BURKE, R. K. Cinesiologia e anatomia aplicada. Rio de Janeiro: Guanabara Koogan S.A., 1977.

ROSENFELD, A. O mito e o herói no moderno teatro brasileiro. São Paulo: Perspectiva, 1982.

SANTAELLA, L. Porque as comunicações e as artes estão convergindo? São Paulo: Paulus, 2005.

SPOLIN, V. Jogos teatrais na sala de aula: o livro do professor. São Paulo: Perspectiva, 2003. Tradução de Ingrid Dormien Koudela.

STANISLAVSKI, C. A construção da personagem. Rio de Janeiro: Civilização Brasileira, 1982.

Criação de um papel. Rio de Janeiro: Civilização Brasileira, 1995.

. A construção da personagem. Rio de Janeiro: Civilização Brasileira, 1996. 